\title{
The Thinking about Bilingual Teaching Practice of Finance in Chinese University
}

\author{
Jing Zhang \\ School of Finance \\ Shandong University of Finance and Economics \\ Jinan City, Shandong Province, China
}

\begin{abstract}
As Chinese economy opens deeper, bilingual teaching has become more and more important in the cultivation of financial talents. However, as a new teaching mode, there are many problems in the actual teaching process of financial bilingual courses. Based on the author's practice, some thoughts on the financial bilingual class are discussed in this paper, including the orientation of bilingual class, the design of teaching methods, and the evaluation of teaching effect and so on. The paper also puts forward four suggestions such as simplification of teaching materials, small class teaching, case teaching and promoting the teaching ability of young teachers, which can provide some help for the development of Chinese bilingual teaching in Finance.
\end{abstract}

Keywords-Finance; bilingual education; teaching means; teaching effect

In the past thirty years, with the deepening of China's reform and opening up, the two-way communication of "going out and coming in" has flourished in various fields. In order to establish a prosperous economic base for the whole country, the cultivation of financial talents with international practice has become the primary task for financial specialty in all of the universities. As a result, all kinds of universities introduce international advanced training programme from different ways. The first-class universities often rely on international bestselling materials and employ well-known international Chinese economists to teach students so that they are able to provide international frontier professional training for students directly, which can not only keep pace with the international famous universities in the teaching of knowledge, but also create a very good and international environment to Chinese students in the training of learning methods. However, for most of the secondclass colleges and universities, it is impossible to have such financial resources and opportunities. So most of them provide the students with access to international professional fields by offering professional bilingual classes. But because the professional bilingual teaching is still a new teaching mode, coupled with the uneven level of teachers, there are a lot of confusion and problems in the specific teaching process. Therefore, this article intends to provide some useful suggestions for the development of financial specialty bilingual teaching on the basis of the author's six-year experience of teaching bilingual classes and visiting abroad for one and half years.

It is funded by the education project, "A Research on the mode of Classification Cultivation of Undergraduate Talents in Finance (2015M105)”.

\section{The ORIENTATION OF Bilingual COURSES IN FinANCE}

When you decide to teach a bilingual financial lecture, first of all is determining why you set it and what the purpose is[1]. In author's opinion, for the financial specialty, the purpose of bilingual class should be based on the international professional research line rather than train students' English ability because bilingual class is not a continuation of English course after all. Therefore, its position must pay attention to professional extension and expansion, just only using English, non-native language, to express and analyze. When teachers design the syllabus and arrange the course content, they should first concern the connection with the student's prerequisite courses, which can't be a repetition of the previously learned course (because it will make the student lose interest in learning and think that the bilingual class is only the previous course of English expression), nor overly overstating the professional level and totally breaking away from the prerequisite courses (which will make students lose confidence in learning, resulting in excessive psychological pressure).

In the case of financial specialty, junior students in university have already completed compulsory courses such as "Finance", "Financial Market" and "International Finance". Therefore when the bilingual classes are offered, teachers should establish the core content of the outline according to the direction of the bilingual class. For example, the bilingual class offered by the author is "Financial System and Economy", which belongs to the field of macroeconomic research, so the main content will closely focus on the relationship between financial system and economic growth, including the impact of different financial structure on economic growth, the vulnerability of financial system and the financial crisis, the effect of financial regulation on economic growth, the influence of financial system efficiency on economic growth, etc. Obviously, students have already learned the basic contents like the functions, structure, vulnerability, crisis and regulation and efficiency of the financial system. So on the one hand, the positioning of the bilingual financial course is to supplement what the previous professional courses do not involve or may lack of profound discussion. On the other hand, the key is the professional level upgraded effectively, which can lead students to think about the status and role of finance in the economic operation more comprehensively and more in-depth, while the whole teaching content can't exceed the ability and scope afforded by students. Of course, in the specific content arrangements have yet to be further carved. 


\section{THINKING OF THE FINANCIAL PROFESSIONAL Bilingual TEACHING MEANS}

The selection and application of teaching methods are the core problems faced by all teachers in the teaching process of course[2]. So is it in the teaching of financial bilingual classes. Combined with the author's practice, there are some key points involving the process of professional bilingual teaching as follows:

\section{A. The Arrangement of Teaching Language}

Obviously, bilingual class must be taught in both languages at the same time. Therefore, it is not advisable for some teachers to use English completely in lectures and it must be in conflict with the positioning of bilingual classes so as to evolve into English class. However, a prominent question is how to reasonably arrange the proportion of the two languages, which means speaking more English or more Chinese. The author believes that a reasonable proportion must be based on the object, that is, the student's ability to accept, because any fundamental purpose of teaching is to make students maximize to master the knowledge and learn professional study methods. If the student's English ability is generally strong, the teacher can speak English as much as possible to make students contact with more professional English expression. If not, the teacher should adopt a step-by-step approach, which is appropriate to reduce the proportion of English expression in the entire teaching especially at the beginning. And then with the students' adaption, the teacher can gradually increase the proportion of English. In general, one of the core principles is that students must be able to master the professional knowledge and thinking methods.

In addition, the author does not agree with some teachers' teaching by English in one lesson and Chinese in another lesson because of the main two reasons. First, from the view of man's psychological characteristics, the same content of the two sections of the repetition is likely to cause students burnout, which leads to weak the learning interest. Second, from the existence time of memory, in the current China's universities there is generally an hour and a half with two lessons. If the first half of both classes is taught in English and then teacher repeats the contents of the front with Chinese in the second half of the class, it is easy to cause memory logical confusion so that the professional knowledge acceptance degree of students would be greatly reduced and the teaching effect will be influenced negatively. The author's experience is using both English and Chinese at the same time. If most students can easily understand the knowledge by the teacher's English expression, teacher does not have to spend time to repeat or explain in Chinese. But if students can't generally master the key points, the teacher must immediately make the corresponding explanation by Chinese.

\section{B. The Problems in Production of Teaching Slides}

Bilingual teaching power-point must fully use the English language to express, which is the basic requirements of professional bilingual class and also is conducive students to familiar with the teaching content and can deepen the memory when students have preview. However, teachers are still plagued by a problem that is whether using the slides _established by foreign professors or making them by themselves. Obviously, the two ways have the advantages and disadvantages respectively. Borrowing foreign power-points is easier and foreign language expression is usually more accurate and the system is more complete. But the teacher would face troubles that their ideas are limited and the teaching logic must be based on others during the teaching process. If teachers remake new slides by themselves, the advantage is that they can base on their teaching ideas to design the content and logic, which is more conducive to play their professional advantages. While the cost is not only to spend a lot of energy and time, but there may be lack of accurate statements in a certain extent. The author's view is to advocate teachers to make their own slides based on the following four reasons.

First, as a university teacher and a professional scholar, the basic professional ethics is to respect intellectual property rights and exert their own professional initiative. Second, the production of making slides is more beneficial teachers to control the instructional pace in the class and highlight their own professional research advantages. Third, through the working process teachers could straighten up the teaching thinking of the whole course as well as master the greater initiative in the lecture. At the same time it also can improve the slides quality and teaching effect and help teachers find scientific research problems, even stimulate the teachers' instruction and study enthusiasm through constantly revising the slides by the teaching feedback. Fourth, now the vast majority of foreign slides are imperfect due to the single form and monotonous color. The author believes that the course power-points should be vivid by more colorful patterns and the corresponding animation. Through a variety of forms to show the curriculum contents and to distinguish the different importance and level of knowledge points, the teachers can clear and definite both their teaching objectives and arrangements, which can help students easily understand the main contents of the course and even somehow arouse students learning interest .

\section{The Arrangement of Teaching Interaction}

Interactive teaching is an important part in bilingual teaching[3]. But how should teacher interact with students? During the teaching process of specialized courses in colleges and universities, there are many ways of interaction such as classroom questioning, student presentation, and group discussion and so on. For the bilingual course, the key is how to arrange the reasonable interaction in the limited class time, the duration of each interaction and how to combine with interaction and lecture. Using for the modern teaching modes, the author mainly adopted two interactive ways that include classroom questioning and group presentation in bilingual teaching. The questioning in class running through the whole process of each lecture covered the review of previous knowledge, the expression of views on some financial phenomena in the real economy and the important content in English reading materials as supplement to deepen the students' memory. The students' group presentation was given the different topics and finished according to their professional interest and freely determined by the members of the group. On the basis of group choice and coordination and distribution of responsibilities, the groups ultimately made the slides to give a speech for the whole class. In this regard, the author's 
experience has confirmed it is a good way because students' presentation can promote training students' professional research ability and professional English expression and the cultivation of team cooperation. But whether the desired results can be achieved depends on two vital factors. One is whether the students are able to grasp the topic mentioned by the teacher. Too large or too deep of the topic often because students to handle poorly and become a mere formality, which need the teacher must put forward the topics seriously. The other is how to consider each member's contribution in the group. There obviously exist the "free-riding" behaviors due to asymmetric information so that it is particularly important designing the suitable rules to encourage students to participate in a real instructional interaction. In addition, in the actual bilingual teaching, there are also many problems such as the students' presentation overtime so as to squeeze the normal lecture time and the students' inaccurate or tedious expression.

\section{Evaluation of Student Achievement}

Bilingual course is not only a window for students to contact with international advanced professional research field, but also a transitional stage for many students who want to go abroad for further study[4]. Therefore, the author thinks that it is necessary to try our best to integrate with the international university education mode. But based on the reality in China it should not be completely copied because of the number of students' courses. In China's university, there are much more courses in one semester than in foreign university. If the examination methods in foreign universities are completely introduced, the burden of China's students will be significantly increased and it will cause students to be lack of energy and power to study the professional bilingual course even lost the interest and eventually give up to choose the bilingual course. So the author thinks that based on the students' daily learning assessment the evaluation methods should still focus on the midterm and final exam. The total score proportion of the two tests can occupy $60 \%-70 \%$. As to the usual study process, the teacher should strengthen the evaluation on students' professional reading. However, the amount of extracurricular reading materials should not be too large. In one semester, it is appropriate to require students reading 3-4 papers with short and medium length. And the evaluation of interactive section will be included in the total score as well.

\section{EVALUATION ON TEACHING EFFECT OF BILINGUAL TEACHING IN FINANCE}

At present, in order to improve the quality of teaching, all universities pay much attention to teachers' teaching assessment and has formed a relatively complete and standardized evaluation index system and evaluation procedure[5]. So how should we evaluate the effect of bilingual teaching? The author believes that based on the characteristics of bilingual course, besides the assessment of conventional teaching effect involving in teaching attitude, teaching content, teaching means and so on, first of all should be added is the aspect about curriculum setting and outline arrangement. Many financial professional bilingual courses are new subjects and most of the teachers are young teacher with the overseas education background but short of the teaching experience. Then in the teaching effect evaluation, it can be beneficial to revise teaching syllabus and improve the teaching quality of bilingual course and realize the student-centered educational philosophy by the assessment of the necessity of setting up the bilingual course, the content and some questions feedback like the specialty depth or the teaching schedule's reasonableness. Secondly, it is also necessary considering to add students' evaluation on their own efforts and gains in the whole bilingual teaching[6], which on one hand can induce students to think about themselves learning gain and loss in the process calmly so that they can accomplish self-evaluation, self-reflection, and true synergistic effect between teachers and students and then stimulate students' learning enthusiasm, on the other hand, through the students' answers, can help teachers find the problems of the curriculum teaching or their own shortcomings from a new angle so as to provide effective evidences for improving the teaching quality. For this reason, the author has been conducting two questionnaire surveys at the beginning and in the end of the semester and achieved much useful information on bilingual course.

\section{Some Suggestions on BiLIngual Courses IN FINANCE}

It is an urgent task for financial specialty in university to set up bilingual teaching, which is also an immediate requirement for students. In the 21st century, financial talents must be international. It is no time to delay to offer the professional bilingual courses for students in financial major. With the previous description and analysis, there are the following four suggestions.

\section{A. Teaching Materials Being Simplified}

Financial bilingual courses are generally offered in the third grade of the undergraduate and the major elective courses are mostly two class hours per week. So in the author's view the class time is not very abundant. Considering the graduate entrance exam and the professional certificates test, etc. so junior students couldn't take the excess burden and pressure and then the bilingual curriculum materials should be simplified, which means teaching contents should not contain too much, too extensive. Of course, teachers need to provide students with some requisite supplementary reading materials to expand the students' field of vision and deepen the professional depth in the teaching process. It is regrettable that most of the current best-selling classic textbooks are mostly thick and unsuitable for bilingual teaching materials to Chinese undergraduates. And if only selecting some parts of the chapter as the content, it may undermine the coherence of knowledge.

\section{B. Effect of Small Class Teaching Better}

With the bilingual teaching practice, the author finds that the effect of small class teaching is better, which the amount is best to keep in about thirty students. Mainly reasons are that there is little chance to interact between teacher and students in a large class so that many Chinese students will not be able to get the exercise of specialized English expression because of their shy of speaking. At the same time, the large class teaching is not conducive to organize class discussion according to freeriding phenomenon as well as let students give their opinions fully. If the great number of students were divided into small 
groups, due to the group number and the limited class time it is very difficult to complete the discussion task.

\section{Relying on Reality to Carry Out Case Teaching}

The purpose of bilingual teaching in Finance is to improve the undergraduates' professional quality and level. Based on the support of professional basic courses, students should try to use the professional knowledge to analyze and explain some real economic problems and phenomenon. Therefore, relying on real cases to teach is both the essential requirement and an important feature of financial bilingual lecture. In the author's opinion, teachers can be with the help of internet resources such as videos, web news, the famous economist's blog to start all-round teaching and discussing the issues happened in different historical period or the current real economy. It can't only attract the attention of students, stimulate their interest in learning, encourage them to apply their knowledge and accomplish the combination of theory and reality, but also prompt the teaching effect through the multiform styles and modes.

\section{Enhancing Teachers' Bilingual Teaching Ability As Soon As Possible}

Professional bilingual teaching requires a higher level of professional teachers, who should have both a higher academic level and better English. The former means that teacher has already achieved a certain level of professional research ability and the latter means teacher had better own overseas study experience so as to deliver the international frontiers knowledge to students preferably. However, in financial specialty of the current common universities, there extremely lacks of the kind of faculty and talents. Now it is good news that some China's high-level universities can supply bilingual teacher training to improve teachers' instructional ability in a short period of time and at a lower cost.

\section{CONCLUSION}

Following the above analysis, we can find the bilingual subject in Finance specialty is an important and necessary course for undergraduates especially thinking about the rapid development and opening degree of China's economy. However, during the process of teaching bilingual class, there have always been many problems such as the purpose of setting up it, the specific arrangement of both languages, how to make the teaching power-points, the settlement of teaching interaction with students in the class, how to grade the students' study and evaluate the teaching effect. In the author's opinion, financial bilingual course is a professional subject in essence just using both English and Chinese. When it is taught, for the teacher, crossing usage of both languages and making own teaching slides are better choices. At the same time various types of interaction activities are beneficial to enhance the students' enthusiasm and assess their learning achievement. And the evaluation of teaching effect should be on the basis of the curriculum setting, outline arrangement and students' feedback beside the common standards. In order to popularize bilingual course in Finance specialty and improve its teaching effect, the author thinks that we should simplify the teaching materials, strive to teach in small-class, apply more real cases and strengthen the teachers' capacity continuously.

\section{ACKNOWLEDGMENT}

The author thanks for the support of the Education Department in Shandong Province and her postgraduates' help.

\section{REFERENCES}

[1] Q Liao, "The Concept of Bilingual Teaching Management and Its Theories Basis”, Education Teaching Forum, vol. 27, pp. 23-25, 2017. (In Chinese)

[2] FF Sun, $X$ Zhou and RL Wu, "A Review and Frontier Analysis of the Research Status of Ethnic Bilingual Education since 2000”, Bilingual Education Studies, vol. 4, pp. 26-38, 2017. (In Chinese)

[3] S Xu, X Zheng, S Wei and Y Pu, "Exploration and Innovation of Special Pedagogy Bilingual Course Construction and Teaching Practice", Journal of Chongqing Normal University Edition of Social Sciences, vol. 6, pp. 61-67, 2016. (In Chinese)

[4] YT Yang, TU Chang-Zheng, JY Shi, LI Jun-Li and NB Hou, "Exploration and Practice of Bilingual Teaching in Normal Universities in Southwest of China”, Guangzhou Chemical Industry, vol. 45, pp. 212213, 2017. (In Chinese)

[5] Y Zheng and X Chen, "How to Activate Students' Learning Initiatives in Bilingual Teaching of International Finance", in Proceedings of the 2017 2nd International Conference on Politics, Economics and Law (ICPEL 2017), Proceedings series "Advances in Economics, Business and Management Research”, doi:10.2991/icpel-17.2017.5.

[6] H Ma, "Practice and Reflection on Bilingual Teaching on Course of Principles of Economics", Proceedings of the 2016 7th International Conference on Education, Management, Computer and Medicine (EMCM 2016), Part of series "Advances in Computer Science Research”, doi:10.2991/emcm-16.2017.170. 